CHARLES RIDDLE is manager of the journalism programme at WINTEC, Hamilton.

\section{Hotchpotch, dry but worthwhile insights}

Beyond the Frontline, by Mike McRoberts. Auckland: Harper Collins, 2011, 256 pp. ISBN 978-1869509392

$\mathrm{T}$ HE EMBERS of the ongoing debate about the paucity or otherwise of in-depth foreign affairs coverage in New Zealand media will glow a little more brightly with this offering from Mike McRoberts.

McRoberts' trips abroad in his dual role as newsreader/journalist have made for good television-but have left some pondering the worth of 'the New Zealand voice' in mostly one-off stand-ups from world trouble spots.

McRoberts does not like to characterise himself as a 'war correspondent' and is wary of the pejorative nature of the term 'parachute journalist'. Yet, he is clearly more than a bit of both as his rather prosaic documentation of his, at times, extraordinary experiences around the globe demonstrates.

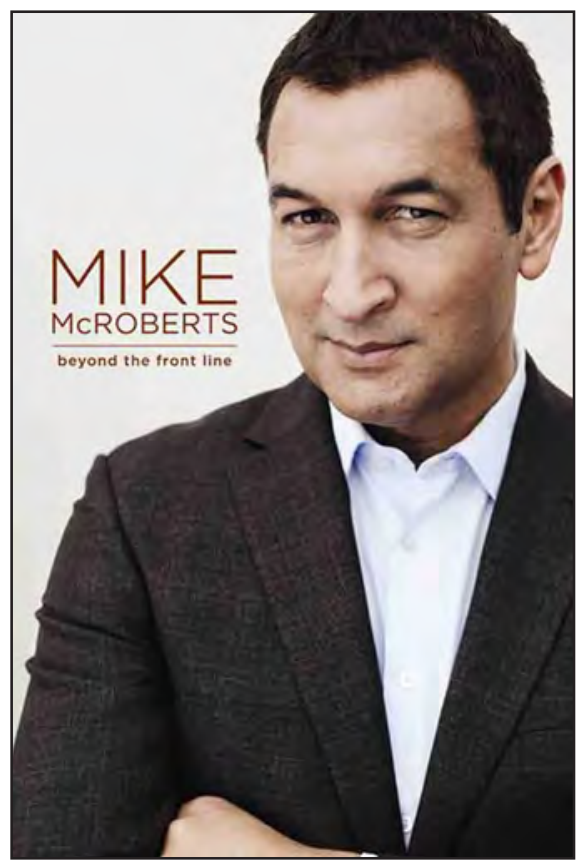

Quite why what one calls him should matter seems a bit off to the side-until one recalls that we do have on file an intriguing stoush between Jon Stephenson (he of the dual Bayeux-Calvados awards for war correspondents) and media commentator David Cohen before the Press Council (2007), part of which involved discussion of what constitutes a foreign correspondent.

And McRoberts' dual role at TV3 has raised eyebrows-some commentators have difficulty with the manner in which he can put himself in the story, while others, such as Brian Edwards, have questioned whether 
the mixed newsreader/journalist role is as successful in attracting viewers as TV3 would have us believe.

Such mastications aside, this is in an informative, interesting, hotchpotch of a book, told by a brave and innovative journalist who only partly succeeds in his aim of taking readers beyond the sound-bites to the stories behind. He is not helped by his broad canvas, which includes a chapter on reporting sports-surely an oddity in a text mostly focused on disasters in Afghanistan, Iraq, the Lebanon, the Philippines, Fiji, Burma, New Zealand, Haiti, among others. In fact, one is left with the feeling McRoberts has been defeated by his own material. His sparse style and understated delivery leaves the reader feeling devoid of sufficient graphic description, and the impression that his own stories are beyond him to tell.

This disappointment aside, however, the book has a great deal to commend it. There are, for example, some genuine tales of 'derring-do' that should enthuse any journalist, such as the occasion his team hid from the Israeli Defence Force in a school inside the Jewish settlement of NeveDekalim in Gaza, just before the settlers were forcibly removed. Emerging from their hiding place that night they were able to film the forced evictions and capture exclu- sive pictures that went around the world. They later blended back into the official media corps tour-which had been issued with identifying red caps by the IDF-by using similar headgear handed out by Emirates staff at Auckland airport.

Other vignettes include McRoberts, who was using Stephenson as his producer, finding himself hurtling into Baghdad along the dangerous $16 \mathrm{~km}$ airport highway in a two-car convoy, his only communication with Stephenson in the following car limited to a walkie talkie set purchased from The Warehouse. Then there is the time he found himself using a Japanese porn-video store's fast internet to upload a story; the story on how to get a scrambled eggs breakfast in devastated Baghdad; the occasion fellow Kiwi TeKimiti Gilbert, who was involved in UN de-mining in the Lebanon, greeted McRoberts with a hongi, much to the delight of the guards at the compound gate; and the time he hid in an ambulance in the Philippines to get to the scene of a mudslide that buried a village.

Among the war stories there are some useful references to the practice of journalism and the problematic issue of involving oneself in the story. McRoberts relates his role in helping an injured Haitian girl to get medical treatment following the 2010 
earthquake that all but flattened Port au Prince. His decision to be open about this, and to report and blog on it, opened up the usual debate among media commentators about journalists intervening in the stories they tell. He was criticised but, really, those on the sidelines can debate but should not judge.

As if to reinforce his position, McRoberts describes another incident in which he screams at American troops in Baghdad to let a man carrying his wounded daughter through a checkpoint to reach a hospital. Those who remember Kevin Carter's 1994 Pulitzer-winning photograph of an emaciated Somali girl being stalked by a vulture will know Carter was criticised for taking an opposite stance and not involving himself in the story.

McRoberts has interesting stories to tell, some good points to make and, if you can get beyond the modest, at times dry, delivery, he is a worthwhile read.

\section{Reference}

New Zealand Press Council (2007). Case 1089 Jon Stephenson against National Business Review. Retrieved on 20 April 2012, from www.presscouncil. org.nz/display_ruling.php?case_number $=1089$

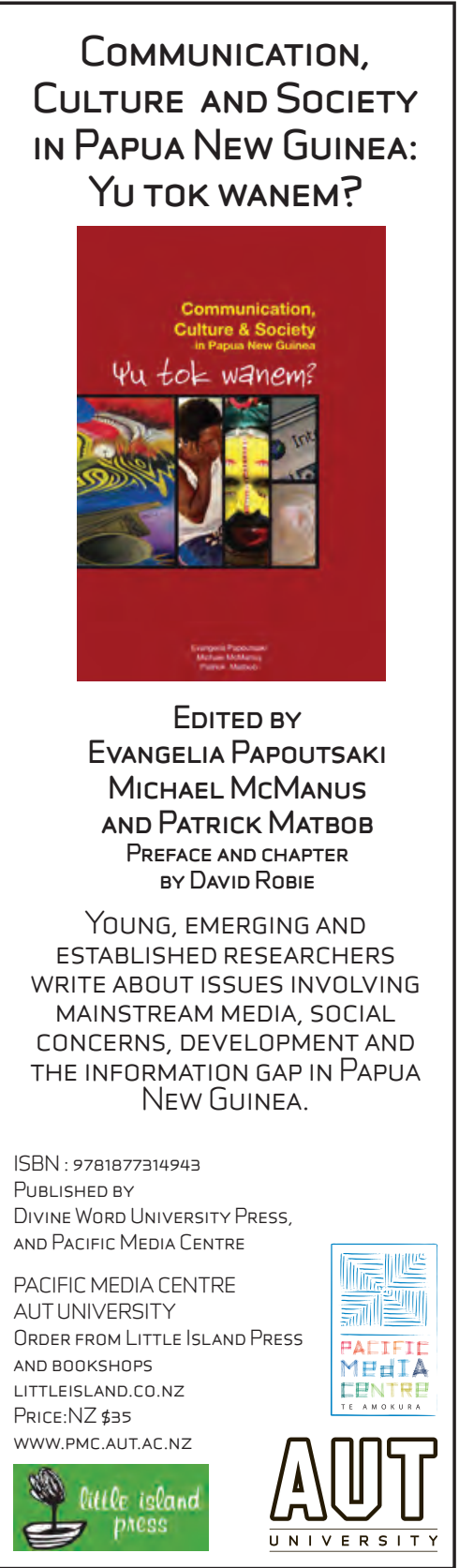

